Copyright (C) 2020 by Academic Publishing House Researcher

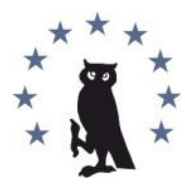

Published in the Russian Federation

European Researcher. Series A

Has been issued since 2010.

E-ISSN 2224-0136

2020, 11(2): 71-81

DOI: 10.13187/er.2020.2.71

www.erjournal.ru

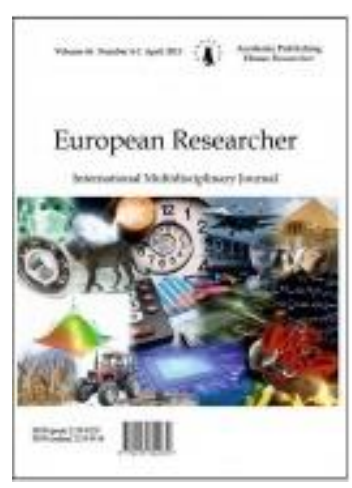

\title{
The Establishment of a System of Pre-professional Training "JuniorSkills" by the Forces of Institution of Additional Education
}

\author{
Natal'ya A. Kovenko a, Irina A. Lelyukh a, Anvar M. Mamadaliev a, , ${ }^{*}$ Elena A. Poluyan a \\ a The station of young technicians in Sochi city, Russian Federation
}

\begin{abstract}
The article is devoted to the analysis of prospects, conditions, opportunities, problems and risks of establishment on the basis of additional education institutions of technical orientation, in particular, the municipal budget institution of additional education for young technicians in Sochi, the system of pre-professional training "JuniorSkills". The paper highlights the relevance, goals and objectives of the project for the preparation of "JuniorSkills" in terms of Sochi city, as well as its conceptual foundations; an analysis of the already done work is made in this direction in the Russian Federation and the possibility of organizing the appropriate infrastructure for Sochi city.

Keywords: "JuniorSkills", Technopark, Sochi, resort city, municipal budgetary institution of additional education in Sochi, pedagogical modeling.

\section{1. Введение}

Национальный проект «Образование», задающий траекторию развития отечественного образования в 2018-2024 годах, ставит своими целями «..обеспечение глобальной конкурентоспособности российского образования» (Национальный проект «Образование», 2018) и «...воспитание гармонично развитой и социально ответственной личности» (Национальный проект «Образование», 2018). Это возможно при развитии актуальных направлений деятельности образовательных учреждений.

Постановление главы администрации (губернатора) Краснодарского края от 5 октября 2015 г. N 939 «Об утверждении государственной программы Краснодарского края «Развитие образования» создало дополнительный нормативно-правовой стимул для активизации меры по модернизации образования и повышению его качества в регионе.

Как известно, еще 10 августа 2015 года на Генеральной Ассамблее международной организации WorldSkills International в г. Сан-Паулу (Бразилия) Россия выиграла право проведения мирового чемпионата по профессиональному мастерству по стандартам «Ворлдскиллс», которые были проведены в 2019 году. Не будет преувеличением тезис о том, что развитие данного направления является устоявшимся мировым трендом и российская система образования также должна следовать в духе этого тренда.

Направлениями деятельности международной организации WorldSkills International согласно ее Уставу, являются популяризация профессий, построение карьеры, обучение и профессиональная подготовка, международное сотрудничество, исследования в области
\end{abstract}

\footnotetext{
${ }^{*}$ Corresponding author

E-mail addresses: anvarm@mail.ru (A.M. Mamadaliev)
} 
профессиональных навыков, а также организация мировых чемпионатов WorldSkills крупнейших соревнований по профессиональному мастерству.

Реализация проекта «Технопарк г. Сочи. Подпроект «Профессионалы Будущего», предусмотренного темой краевой инновационной площадки (выполняемого в рамках федеральной инновационной площадки по теме «Технопарк в г. Сочи) позволит на качественно новом уровне выстроить образовательный процесс с полновесной ориентацией на профессию, приобщением к достижениям современной науки и техники; причем, проектируемая нами модель является универсальной и без кардинальной доработки сможет быть использована не только в условиях города-курорта Сочи, но и в других муниципалитетах и регионах. Непосредственным результатом реализации нашего проекта станет действующая система подготовки по направлениям «Юниор-Профи» (JuniorSkills) в г. Сочи.

\section{2. Материалы и методы}

Материалом для данной статьи послужили нормативно-правовые акты в сфере образования, а также научно-методическая литература.

Предмет нашего исследования прямо или косвенно регламентируют такие нормативные акты как Конвенция о правах ребенка, Конституция Российской Федерации, Федеральный закон Российской Федерации от 29.12.2012г. №273-Ф3 «Об образовании в Российской Федерации», Национальная образовательная инициатива «Наша новая школа» (утв. Приказом Президента РФ от 4 февраля 2010 г. № Пр-271), государственная программа Российской Федерации «Развитие образования» на 2013 - 2020 годы» (утв. Постановлением Правительства РФ от 15 апреля 2014 г. № 295), Закон Краснодарского края от 16.07.2013 г. №2770-КЗ «Об образовании в Краснодарском крае», государственная программа Краснодарского края «Развитие образования» на 2016-2021гг. (утв. Постановлением от О5 октября 2015 года № 939 губернатора Краснодарского края В.И. Кондратьева), концепция Федеральной целевой программы развития образования на 2016-2020 годы, концепция общенациональной системы выявления и развития молодых талантов, концепция модернизации Российского образования на период до 2020 года, концепция развития дополнительного образования детей (утв. Распоряжением Правительства РФ от 4 сентября 2014 г. № 1726-р), концепция долгосрочного социально-экономического развития Российской Федерации на период до 2020 года, стратегия инновационного развития Российской Федерации на период до 2020 года, стратегия развития воспитания в Российской Федерации на период до 2025 года, перечень поручений Президента РФ по итогам заседания Государственного совета по вопросам совершенствования системы общего образования, 23 декабря 2015 года, Постановление Правительства РФ от 15.04.2014г. №295 «Об утверждении государственной программы РФ «Развитие образования на 2016-2020 годы», Федеральные требования к образовательным учреждениям в части охраны здоровья обучающихся, воспитанников, утверждены приказом министерства образования и науки РФ от 28.12.2010 №2106, Федеральные требования к образовательным учреждениям в части минимальной оснащенности учебного процесса и оборудования учебных помещений, утверждены приказом министерства образования и науки РФ от 04.10.2010 г. № 986, а также Указ Президента РФ от 7 мая 2012 №599 «О мерах по реализации государственной политики в области образования и науки».

На основе указанных документов были созданы внутренние нормативные акты Муниципального бюджетного учреждения дополнительного образования Станция юных техников в г. Сочи: Программа развития муниципального бюджетного учреждения дополнительного образования станция юных техников г. Сочи (2020-2023), Программа федеральной инновационной площадки «Технопарк г. Сочи», а также Положение об инновационной деятельности МБУ ДО СЮТ в г. Сочи.

В работе над проектом были использованы несколько групп методов исследования: общетеоретические (анализ научной литературы и нормативной базы, синтез, обобщение), эмпирические (педагогическое моделирование; устный опрос; беседа; тестирование; анкетирование; наблюдение) и статистические (методы математической обработки данных). 


\section{3. Обсуждение}

С учетом относительной новизны нашей темы, проблема предпрофессиональной подготовки еще не освещена достаточно полно, однако начинает стремительно набирать популярность, особенно учитывая пристальное внимание этому вопросу российской власти вплоть до самого высокого уровня.

Вместе с тем, советская педагогика и психология (имеем ввиду психологию труда) достаточно глубоко и скрупулезно изучала возможности предпрофессиональной подготовки силами как общеобразовательных организаций, так и учреждений дополнительного образования детей.

Прежде всего, необходимо отметить работы профессора Евгения Александровича Климова, который занимался проблемами допрофессиональной подготовки и психологии труда занимался с начала 6о-х годов XX века. Автором были проанализированы роль влияния психологических особенностей личности на индивидуальный стиль деятельности (включая и трудовую) (Климов, 1969), особенности процесса выбора профессии старшеклассником, а также практические советы с точки зрения психологии (Климов, 1990; Климов, 1993) и др. Одним из главных достижений Е.А. Климова стали два фундаментальных труда: общепризнанное в вузах не только в России, но и других регионах постсоветского пространства учебные пособие, которое начиная с 1988 года выдержало множество изданий, вплоть до настоящего времени (Климов, 1988), а также монография, посвященная психологическим проблемам профессионального самоопределения (Климов, 2004). Не будет большим преувеличением тезис, касающийся теоретического обоснования WorldSkills о том, что «все новое - это хорошо забытое старое».

Современным последователем «школы Климова» стала Г.В. Резапкина. Автор разработала программу для облегчения профессионального самоопределения подростков (Резапкина, 2000), в то числе и предпрофильной подготовки для 9-классников (Резапкина, 2005b), а также написанное легким и доступным языком наглядное пособие для помощи в выборе профессии (Резапкина, 2004). Также в других ее монографиях поднимались психологические вопросы выбора профессии (Резапкина, 2006) и особенностям отбора в профильные классы (Резапкина, 2005а). Помимо этого, автор ведет широкую просветительскую и обучающую деятельность в сети Интернет, представляя мастер-классы и блоги по психологическим особенностям и практическим советам по выбору (смене) профессии, в том числе - для людей среднего и предпенсионного возраста.

И.С.Ароном был исследован процесс формирование психологической готовности к профессиональному самоопределению в детском возрасте (Арон, 2010); С.И. Вершининым, Е.А. Сурудиной разработаны методические рекомендации во вопросам осуществления профессионального выбора (Вершинин, Сурудина, 2001); Е.И. Рогов анализирует не только проблему выбора профессии, но и необходимые условия для достижения высоких результатов в процессе трудовой деятельности (Рогов, 2003); М.С. Савина дает методические рекомендации по обучению технологии поиска работы (Савина, 2004), а также в соавторстве с В.А. Солнцевой и А.А. Савиным разработала методические рекомендации по вопросу профориентационного сопровождения профессиональной карьеры (Савина и др., 2001).

Непосредственно соревнованиям WorldSkills посвящены методические материалы Н.С. Королевой, Г.Т. Габдуллиной, Н.П. Орловой, Э.Э. Ульяновой (на примере материалов для проведения «Урока WorldSkills Kazan 2019» в образовательных учреждениях Российской Федерации) (Королева и др., 2019).

Безусловно, мы перечислили только небольшое количество работ, посвященных предпрофессиональной подготовке в целом, и «Юниор-Профи» в частности, однако вышеуказанные работы были непосредственно использованы нами не только для данной публикации, но и в работе Муниципального бюджетного учреждения дополнительного образования Станция юных техников в г. Сочи (далее - СЮТ) над краевой инновационной площадкой «Технопарк г. Сочи. Подпроект «Профессионалы Будущего» в рамках федеральной инновационной площадки «Технопарк в г. Сочи».

\section{4. Результаты}

Развитие цифровой экономики в России - один их национальных приоритетов, закрепленных в Указе Президента РФ № 204 от 7 мая 2018 г. «О национальных целях и 
стратегических задачах развития Российской Федерации на период до 2024 года». «Обеспечение подготовки высококвалифицированных кадров для цифровой экономики» одно из конкретных поручений Указа (Указ Президента РФ № 204, 2018). Аналогичные целевые установки закреплены и в программе «Цифровая экономика Российской Федерации» (утв. распоряжением Правительства РФ № 1632-р 28.06.2017). «Кадры и образование» - одно из базовых направлений программы», в рамках которого в 2019-2020 гг. планируется разработать модели компетенций специалистов цифровой экономики (Цифровая экономика, 2017; п. 2.1), создать формат индивидуальных профилей компетенций граждан (Цифровая экономика, 2017; п. 2.3), внедрить индивидуальные траектории обучения под цели программы для 20\% учащихся школ (Цифровая экономика; пп. 2.4.6). Согласно данным Агентства стратегических инициатив, 65\% нынешних школьников и студентов займут должности, которые еще не существуют (Стратегия РВ, 2015).

С другой стороны, современные школьники и студенты колледжей недостаточно адекватно оценивают перспективы рынка труда, выбирая профессии, не связанные с перспективными экономическими трендами. Эту ситуацию необходимо связывать с неэффективной системой профориентации в школах - так считают 84 \% российских родителей (данные опроса 1,9 тыс. человек, проведенного школой «Летово»; Королева и др., 2019; 9). О той же проблеме говорила в свое время и министр просвещения РФ О.Ю. Васильева: «знакомить наших школьников с профессиями, которые востребованы в регионах - история хорошая» (Королева и др., 2019; 6).

Недостаточно готовы к модернизации экономики и университеты. В этом направлении необходимо формировать карты компетенций (пример - презентованный в конце августа 2018 года «Атлас профессий будущего Калужской области), а также заниматься позиционированием программ региональных университетов (пример - спецпроект «Профессии будущего» НИУ ВШЭ).

Краснодарский край стал одним из «пионеров» внедрения программ «Робототехника» и JuniorSkills («ЮниорПрофи»). С 2018 года эти программы трансформируются в новую целостную модель подготовки будущих инженерно-технических кадров «Профессионалы будущего».

Вместе с тем, проблема отсутствия необходимых образовательных услуг в городе Сочи сохраняется. На сегодняшний день в муниципалитете компетенции «Мобильная робототехника» и «Инженерный дизайн» представлены только в МБУ ДО СЮТ. Отсутствуют учреждения, реализующие концепцию «Юниор-Профи» по компетенциям: «Мехатроника», «Медиакомуникации», «Сетевое и системное администрирование». В г. Сочи отсутствует специализированная зона, которая предоставляла бы возможность обучения предпрофессиональным навыкам в рамках сочетания «технологического образования» и «технологического досуга». Реализация проекта создаст условия для построения и сопровождения индивидуальных траекторий развития обучающихся.

Нами рассмотрен представленный опыт реализации аналогичного проекта в РФ и Краснодарском крае. Ввиду своей актуальности, подобные проекты на сегодняшний день решаются на территории всей страны. «Профессионалы будущего» - это профориентационная выездная программа Центра развития и тестирования «Гуманитарные технологии», созданного на базе факультета психологии МГУ имени М.В. Ломоносова для детей 13-17 лет. В рамках программы дети погружаются в профессию вместе с ведущими тренерами и экспертами, создают проекты и развивают необходимые для профессионала навыки.

В Красноярском крае развивается кейсовое движение «Профессионалы будущего» молодежное сообщество, ориентированное на развитие традиционных отраслей и территории Красноярского края. Ключевым ориентиром Движения является формирование инновационного и системного мышления, профессиональное самоопределение и технологическое развитие участников.

Проект «Профессионалы будущего для цифровой экономики» реализуется Ассоциацией «СМАРТ-Концепт» в партнерстве с Министерством образования Новосибирской области, Агентством формирования инновационных проектов «АРИС», ведущими университетами Новосибирской области и при поддержке средств Фонда 
президентских грантов РФ. Проект направлен на создание платформы для профессионального самоопределения школьников 8-10 классов и студентов колледжей Новосибирской области в контексте развития цифровой экономики (в рамках «профессий будущего») и целевых установок социально-экономического развития Новосибирской области. В рамках проекта развитие регионального кадрового потенциала цифровой экономики региона реализуется через содействие профессиональному самоопределению школьников и стимулирование кооперативных связей между школами, университетами и предприятиями. Проект позволит сформировать региональную карту компетенций специалистов цифровой экономики, повысить интерес учащихся к обучению по востребованным профессиям, способствовать закреплению высокопрофессиональных и мотивированных кадров в Новосибирской области, сформировать партнерство школ, университетов и предприятий Новосибирской области под цели развития цифровой экономики.

Отличие нашего проекта в том, что он реализуется на базе учреждения дополнительного образования, т.е. является практико-ориентированным и опирается на первичную профессиональную диагностику. В ходе его исполнения мы сможем не только изучить профессиональные интересы, но и предоставим площадку («Технопарк») для предпрофессиональных проб по заявленным компетенциям.

Как указывалось выше, одна из задач создания технопарка в г. Сочи - это создание системы предпрофессиональной подготовки Junior Skills по актуальным на сегодняшний день направлениям, таким как «Мобильная робототехника», «Инженерный дизайн CAD (САПР)», «Прототипирование», «Мехатроника», «Аэрокосмическая инженерия», «Электроника», «Мультимедийная журналистика». Отдельной задачей выступает организация предпрофессиональной подготовки людей с ограниченными возможностями.

Реализация проекта напрямую способствует решению сразу нескольких важнейших задач государственной программы Краснодарского края «Развитие образования», таких как:

- развитие инфраструктуры образовательных организаций, обеспечивающих доступ населения Краснодарского края к качественным услугам дополнительного образования детей;

- развитие современных механизмов, содержания и технологий дополнительного образования;

- реализация мер популяризации среди детей и молодежи научно-образовательной и творческой деятельности (Развитие образования КК, 2013).

Отметим основные преимущества нашего проекта:

- на муниципальном уровне будет напрямую выполняться одна из задач национального проекта «Образование» - увеличение доли детей в возрасте от 5 до 18 лет, охваченных дополнительным образованием;

- технопарк станет стартовой площадкой для будущих профессионалов г. Сочи по приоритетным направлениям технологического развития Российской Федерации;

- идею, методический инструментарий и результаты проект можно будет тиражировать в муниципальных образованиях Краснодарского края как после завершения, так и на этапах реализации.

Новизна обусловлена инновационным построением обучения и комплексным подходом в проведении досуга, а именно:

- изучение потребности учащихся в технологическом образовании, проектирование и сопровождение образовательных траекторий наставником;

- предоставление технических видов досуга: моделирование, управление различными видами моделей и роботов, предоставление необходимой технической и технологической помощи.

Отметим также, что на сегодняшний день в г. Сочи технопарков, оказывающих такого рода услуги все еще нет.

Таким образом, основная цель нашего инновационного проекта создание практикоориентированной среды дополнительного образования для предпрофессиональной подготовки обучающихся образовательных учреждений г. Сочи, которая, как нам представляется, может быть решена посредством таких задач как: 
1. Создание нормативной и материально-технической базы для функционирования технопарка;

2. Создание кадровой базы технопарка;

3. Организация деятельности по презентации компетенций «Юниор-Профи»;

4. Организация образовательной деятельности в технопарке (в том числе дистанционное дополнительное образование), а также разработка и внедрение инновационных авторских программ по направлениям «Юниор-Профи»;

5. Разработка модели летнего профильного лагеря как платформы для взаимодействия по обмену лучшими практиками;

6. Формирование муниципальной карты компетенций на основе приоритетов национальной программы «Цифровая экономика» и задач социально-экономического развития Краснодарского края;

7. Обеспечение проведения мероприятий в рамках «пространства проб», тьюторство учащихся при прохождении индивидуальных образовательных траекторий, формирование карты компетенций и профессионального самоопределения для каждого участника по итогам прохождения «пространства проб».

Проект смоделирован таким образом, что может быть реализован с минимальными изменениями не только на уровне муниципалитета, но и в образовательных учреждениях других субъектов Краснодарского края. Это становится возможным благодаря использованию в проекте принципа универсальности методического и дидактического инструментария. Таким образом, результаты проекта будут полезны на краевом уровне, так как могут быть тиражированы без каких-либо серьезных изменений в других муниципалитетах Краснодарского края.

Разумеется, в современных условиях ни один педагогический проект невозможен без сетевого взаимодействия. Луковичная диаграмма, представленная на рис.1, отображает схему сетевого взаимодействия участников проекта.

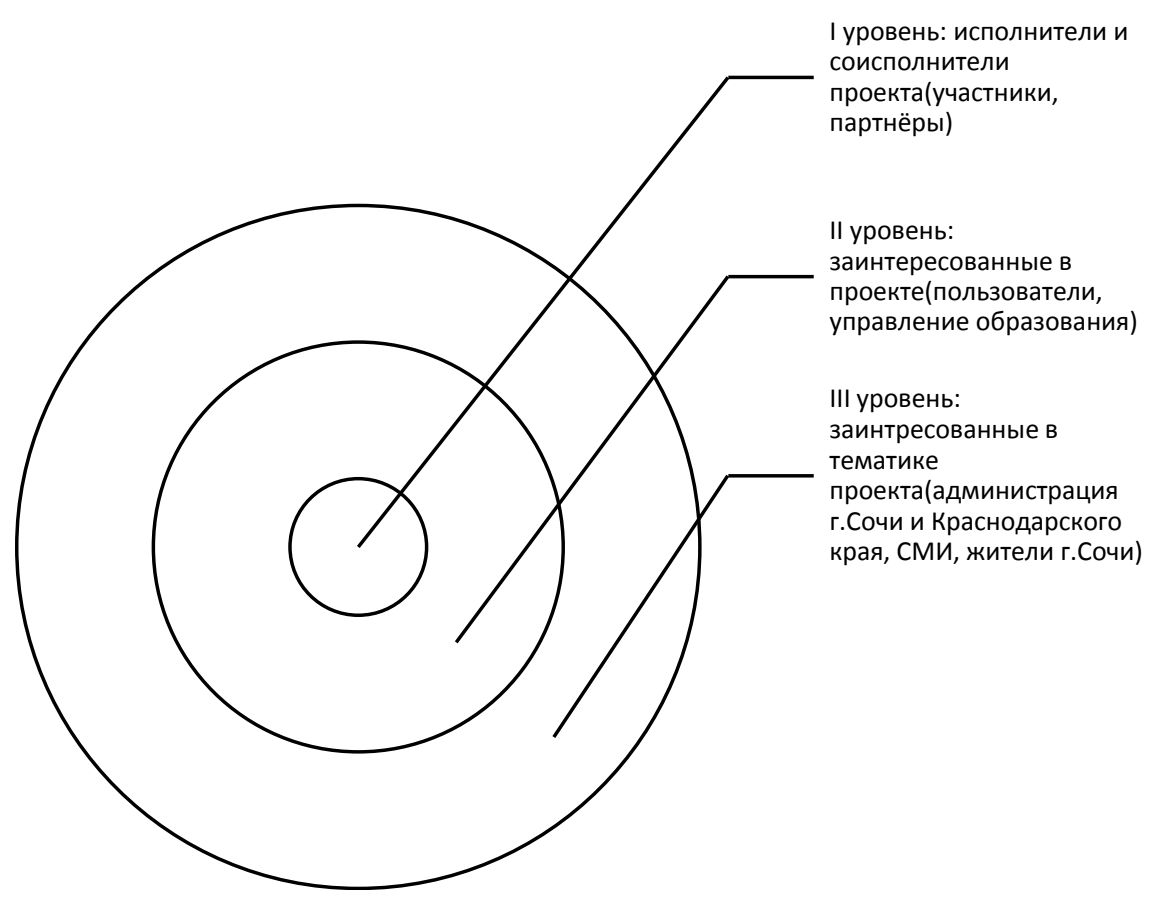

Рис. 1. Сетевое взаимодействие участников проекта «Создание модели практикоориентированной среды дополнительного образования для предпрофессиональной подготовки обучающихся образовательных учреждений г. Сочи»

Для сетевого взаимодействия в группе I заключены (будут заключены) партнерские соглашения. В группе II взаимодействие осуществляется через презентацию проекта родителям обучающихся и управлению образования г. Сочи и открытость мероприятий на базе МБУ ДО СЮТ г. Сочи и на площадках партнеров. Так, например, после первичной 
диагностики будет опубликован срез компетенций на сайте проекта, до родителей будут доведены в индивидуальном порядке предложения по формированию образовательных траекторий их детей. С группой III планируется взаимодействие путем приглашений на мероприятия проекта, предоставляемых отчетов, пресс-релизов, публикаций на сайте.

\section{4. Заключение}

Подытоживая сказанное, отметим ключевые моменты, обозначенные выше:

1. В г. Сочи на сегодняшний день отсутствует система подготовки по актуальным в современных условиях направлениям «Юниор-Профи». Проект «Технопарк г. Сочи. Подпроект «Профессионалы Будущего» в рамках федеральной инновационной площадки «Технопарк в г. Сочи», реализуемый в рамках краевой инновационной площадки позволит устранить этот пробел.

Отличие нашего проекта от реализуемых проектов в других регионах Российской Федерации в том, что он сознается на базе учреждения дополнительного образования, т.е. является практико-ориентированным и опирается на первичную профессиональную диагностику. В ходе его исполнения мы сможем не только изучить профессиональные интересы, но и предоставим площадку («Технопарк») для предпрофессиональных проб по заявленным компетенциям.

2. Основными преимуществами нашего проекта считаем: выполнение на муниципальном уровне одной из важнейших задач национального проекта «Образование» - увеличение доли детей в возрасте от 5 до 18 лет, охваченных дополнительным образованием, создание стартовой площадкой для будущих профессионалов г. Сочи по приоритетным направлениям технологического развития Российской Федерации, а также широкие возможности для тиражирования идеи, методического инструментария и результатов проекта в других муниципальных образованиях Краснодарского края как после завершения, так и на этапах реализации. Неотъемлемой частью реализации проекта является сетевое взаимодействие с партнерами.

\section{5. Благодарности}

Работа выполнена в рамках федеральной инновационной площадки по теме «Технопарк в г. Сочи» и краевой инновационной площадки по теме «Создание модели практико-ориентированной среды дополнительного образования для предпрофессиональной подготовки обучающихся образовательных учреждений г. Сочи».

\section{Литература}

Арон, 2010 - Арон И.С. Формирование психологической готовности к профессиональному самоопределению в детском возрасте. Йошкар-Ола: Марийский институт образования, 2010.

Вершинин, Сурудина, 2001 - Вершинин С.И., Сурудина E.A. Как осуществить профессиональный выбор. Методические рекомендации. М., 2001.

Закон об образовании, 2012 - Федеральный закон Российской Федерации от 29.12.2012г. №273-ФЗ «Об образовании в Российской Федерации». М., 2020.

Климов, 1969 - Климов E.A. Индивидуальный стиль деятельности в зависимости от типологических свойств нервной системы. Казань, 1969.

Климов, 1988 - Климов Е.А. Введение в психологию труда. М.: МГУ, 1988.

Климов, $1990-$ Климов E.A. Как выбирать профессию: Книга для учащихся старших классов средней школы. 2-е изд., доп. и дораб. М., 1990.

Климов, 1993 - Климов E.A. Развивающийся человек в мире профессий. Обнинск: Принтер, 1993.

Климов, 2004 - Климов Е.А. Психология профессионального самоопределения. М.: Академия, 2004.

Конвенция, 1989 - Конвенция о правах ребенка (одобрена Генеральной Ассамблеей ООН от 20.11.1989) // Справочно-правовая система «Гарант».

Конституция..., 1993 - Конституция Российской Федерации. М., 1993.

Концепция модернизации $\mathrm{CO}, 2008$ - Концепция модернизации Российского образования на период до 2020 года // Справочно-правовая система «Гарант». 
Концепция МТ, 2012 - Концепция общенациональной системы выявления и развития молодых талантов // Справочно-правовая система «Гарант».

Концепция развития ДО, 2014 - Концепция развития дополнительного образования детей (утв. Распоряжением Правительства РФ от 4 сентября 2014 г. № 1726-р) // Справочноправовая система «Гарант».

Концепция СЭР, 2018 - Концепция долгосрочного социально-экономического развития Российской Федерации на период до 2020 года // Справочно-правовая система «Гарант».

Концепция ФЦП, 2014 - Концепция Федеральной целевой программы развития образования на 2016 - 2020 годы // Справочно-правовая система «Гарант».

Королева и др., 2019 - Методические материалы для проведения «Урока WorldSkills Kazan 2019» в образовательных учреждениях Российской Федерации // Авторы-составители: Н.С. Королева, Г.Т. Габдуллина, Н.П. Орлова, Э.Э. Ульянова. Казань, 2019.

Национальный проект «Образование», 2018 - Национальный проект «Образование» 2019-2024 гг. [Электронный pecypc]. URL: https://edu.gov.ru/national-project

Наша новая школа, 2010 - Национальная образовательная инициатива «Наша новая школа» (утв. Приказом Президента РФ от 4 февраля 2010 г. № Пр-271) // Справочноправовая система «Гарант».

Об образовании в КК, 2013 - Закон Краснодарского края от 16.07.2013г. №2770-КЗ «Об образовании в Краснодарском крае» // Справочно-правовая система «Гарант».

Перечень компетенций Ворлдскиллс-2017, 2016 - Приложение № 2 к приказу Союза «Ворлдскиллс Россия» от 30 ноября 2016 г. № ПО/19 «Перечень компетенций Ворлдскиллс Россия для проведения демонстрационного экзамена по стандартам Ворлдскиллс Россия в 2017 году» [Электронный ресурс]. URL: https://worldskills.ru/o-nas/dokumentyi/dokumentyipo-proektam

Положение об ИД СЮТ, 2018 - Положение об инновационной деятельности МБУ ДО СЮТ в г. Сочи

Поручения Президента РФ от 23.12.15, 2015 - Перечень поручений Президента РФ по итогам заседания Государственного совета по вопросам совершенствования системы общего образования, 23 декабря 2015 года // Справочно-правовая система «Гарант».

Постановление № 295, 2014 - Постановление Правительства РФ от 15.04.2014г. №295 «Об утверждении государственной программы РФ «Развитие образования на 2016-2020 годы» // Справочно-правовая система «Гарант».

Программа развития СЮТ, 2020 - Программа развития муниципального бюджетного учреждения дополнительного образования станция юных техников г. Сочи. Сочи: МБУДО СЮТ в г. Сочи, 2020.

Программа технопарка СЮТ, 2020 - Программа ФИП «Технопарк г. Сочи». Сочи: МБУДО СЮТ в г. Сочи, 2020.

Развитие образования КК, 2015 - Государственная программа Краснодарского края «Развитие образования» на 2016-2021гг. (утв. Постановлением от о5 октября 2015 года № 939 губернатора Краснодарского края В.И. Кондратьева) // Справочно-правовая система «Гарант».

Развитие образования, 2014 - Государственная программа Российской Федерации «Развитие образования» на 2013 - 2020 годы» (утв. Постановлением Правительства РФ от 15 апреля 2014 г. № 295) // Справочно-правовая система «Гарант».

Резапкина, 2000 - Резапкина Г.В. Я и моя профессия. Программа профессионального самоопределения для подростков. М., 2000.

Резапкина, 2004 - Резапкина Г.В. Скорая помощь в выборе профессии. М., 2004.

Резапкина, 2005b - Резапкина Г.В. Программа предпрофильной подготовки для 9-х классов «Психология и выбор профессии». М., 2005.

Резапкина, 2005а - Резапкина Г.В. Отбор в профильные классы. М., 2005.

Резапкина, 2006 - Резапкина Г.В. Психология и выбор профессии. М., 2006.

Рогов, 2003 - Рогов Е.И. Выбор профессии: Становление профессионала. М.: ВЛАДОСПРЕСС, 2003.

Савина и др., 2001 - Савина М.С., Солнцева В.А., Савин А.А. Профориентационное сопровождение профессиональной карьеры. Методическая разработка. М., 2001. 
Савина, 2004 - Савина М.С. Обучение технологии поиска работы. Методические рекомендации. М., 2004.

Стратегия ИР, 2011 - Стратегия инновационного развития Российской Федерации на период до 2020 года // Справочно-правовая система «Гарант».

Стратегия $\mathrm{PB}, 2015$ - Стратегия развития воспитания в Российской Федерации на период до 2025 года // Справочно-правовая система «Гарант».

Указ Президента № 599, 2012 - Указ Президента РФ от 7 мая 2012 № 599 «О мерах по реализации государственной политики в области образования и науки» // Справочноправовая система «Гарант».

Указ Президента РФ № 204, 2018 - Указ Президента РФ от 7 мая 2018 г. № 204 «О национальных целях и стратегических задачах развития Российской Федерации на период до 2024 года» // Справочно-правовая система «Гарант».

Федеральные требования по оснащенности, 2010 - Федеральные требования к образовательным учреждениям в части минимальной оснащенности учебного процесса и оборудования учебных помещений, утверждены приказом министерства образования и науки РФ от 04.10.2010 г. №986 // Справочно-правовая система «Гарант».

Федеральные требования по охране, 2010 - Федеральные требования к образовательным учреждениям в части охраны здоровья обучающихся, воспитанников, утверждены приказом министерства образования и науки РФ от 28.12.2010 №2106 // Справочно-правовая система «Гарант».

Цифровая экономика, 2017 - Программа «Цифровая экономика Российской Федерации» утверждена распоряжением Правительства РФ от 28.06.2017 № 1632-р // Справочно-правовая система «Гарант».

\section{References}

Aron, 2010 - Aron I.S. (2010). Formirovanie psikhologicheskoi gotovnosti k professional'nomu samoopredeleniyu $\mathrm{v}$ detskom vozraste [The formation of psychological readiness for professional self-determination in childhood]. Ioshkar-Ola: Mariiskii institut obrazovaniya. [in Russian]

Federal'nye trebovaniya po okhrane, 2010 - Federal'nye trebovaniya k obrazovatel'nym uchrezhdeniyam $\mathrm{v}$ chasti okhrany zdorov'ya obuchayushchikhsya, vospitannikov, utverzhdeny prikazom ministerstva obrazovaniya i nauki RF ot 28.12.2010 №2106. Spravochno-pravovaya sistema «Garant» [in Russian]

Federal'nye trebovaniya po osnashchennosti, 2010 - Federal'nye trebovaniya $\mathrm{k}$ obrazovatel'nym uchrezhdeniyam v chasti minimal'noi osnashchennosti uchebnogo protsessa i oborudovaniya uchebnykh pomeshchenii, utverzhdeny prikazom ministerstva obrazovaniya i nauki RF ot 04.10.2010 g. №986. Spravochno-pravovaya sistema «Garant». [in Russian]

Klimov, 1969 - Klimov E.A. (1969). Individual'nyi stil' deyatel'nosti v zavisimosti ot tipologicheskikh svoistv nervnoi sistemy [Individual style of activity depending on the typological properties of the nervous system]. Kazan'. [in Russian]

Klimov, 1988 - Klimov E.A. (1988). Vvedenie v psikhologiyu truda [Introduction to the psychology of work]. M.: MGU. [in Russian]

Klimov, 1990 - Klimov E.A. (1990). Kak vybirat' professiyu: Kniga dlya uchashchikhsya starshikh klassov srednei shkoly [How to choose a profession: A book for high school students]. 2-e izd., dop. i dorab. M. [in Russian]

Klimov, 1993 - Klimov E.A. (1993). Razvivayushchiisya chelovek v mire professii [How to choose a profession: A book for high school students]. Obninsk: Printer. [in Russian]

Klimov, 2004 - Klimov E.A. (2004). Psikhologiya professional'nogo samoopredeleniya [Psychology of professional self-determination]. M.: Akademiya. [in Russian]

Konstitutsiya..., 1993 - Konstitutsiya Rossiiskoi Federatsii [Psychology of professional selfdetermination]. M., 1993. [in Russian]

Kontseptsiya FTsP, 2014 - Kontseptsiya Federal'noi tselevoi programmy razvitiya obrazovaniya na 2016-2020 gody. Spravochno-pravovaya sistema «Garant». [in Russian]

Kontseptsiya modernizatsii SO, 2008 - Kontseptsiya modernizatsii Rossiiskogo obrazovaniya na period do 2020 goda. Spravochno-pravovaya sistema «Garant». [in Russian] 
Kontseptsiya MT, 2012 - Kontseptsiya obshchenatsional'noi sistemy vyyavleniya i razvitiya molodykh talantov. Spravochno-pravovaya sistema «Garant». [in Russian]

Kontseptsiya razvitiya DO, 2014 - Kontseptsiya razvitiya dopolnitel'nogo obrazovaniya detei (utv. Rasporyazheniem Pravitel'stva RF ot 4 sentyabrya 2014 g. № 1726-r). Spravochno-pravovaya sistema «Garant».

Kontseptsiya SER, 2018 - Kontseptsiya dolgosrochnogo sotsial'no-ekonomicheskogo razvitiya Rossiiskoi Federatsii na period do 2020 goda. Spravochno-pravovaya sistema «Garant». [in Russian]

Konventsiya, 1989 - Konventsiya o pravakh rebenka (odobrena General'noi Assambleei OON ot 20.11.1989). Spravochno-pravovaya sistema «Garant». [in Russian]

Koroleva i dr., 2019 - Koroleva, N.S., Gabdullina, G.T., Orlova, N.P., Ul'yanova, E.E. (2019). Metodicheskie materialy dlya provedeniya «Uroka WorldSkills Kazan 2019» v obrazovatel'nykh uchrezhdeniyakh Rossiiskoi Federatsii [Methodological materials for conducting the "WorldSkills Kazan 2019 lesson" in educational institutions of the Russian Federation]. Kazan'. [in Russian]

Nasha novaya shkola, 2010 - Natsional'naya obrazovatel'naya initsiativa «Nasha novaya shkola» (utv. Prikazom Prezidenta RF ot 4 fevralya 2010 g. № Pr-271). Spravochno-pravovaya sistema «Garant». [in Russian]

Natsional'nyi proekt «Obrazovanie», 2018 - Natsional'nyi proekt «Obrazovanie» 20192024 gg. [National project "Education" 2019-2024]. [Electronic resource]. URL: https://edu.gov. $\mathrm{ru} /$ national-project [in Russian]

Ob obrazovanii v KK, 2013 - Zakon Krasnodarskogo kraya ot 16.07.2013g. №2770-KZ «Ob obrazovanii v Krasnodarskom krae» // Spravochno-pravovaya sistema «Garant». [in Russian]

Perechen' kompetentsii Vorldskills-2017, 2016 - Prilozhenie № 2 k prikazu Soyuza «Vorldskills Rossiya» ot 30 noyabrya 2016 g. № PO/19 «Perechen' kompetentsii Vorldskills Rossiya dlya provedeniya demonstratsionnogo ekzamena po standartam Vorldskills Rossiya V 2017 godu» [Electronic resource]. URL: https://worldskills.ru/o-nas/dokumentyi/dokumentyi-po-proektam [in Russian]

Polozhenie ob ID SYuT, 2018 - Polozhenie ob innovatsionnoi deyatel'nosti MBU DO SYuT v g. Sochi. [in Russian]

Porucheniya Prezidenta RF ot 23.12.15, 2015 - Perechen' poruchenii Prezidenta RF po itogam zasedaniya Gosudarstvennogo soveta po voprosam sovershenstvovaniya sistemy obshchego obrazovaniya, 23 dekabrya 2015 goda. Spravochno-pravovaya sistema «Garant».[in Russian]

Postanovlenie № 295, 2014 - Postanovlenie Pravitel'stva RF ot 15.04.2014g. №295 «Ob utverzhdenii gosudarstvennoi programmy RF «Razvitie obrazovaniya na 2016-2020 gody». Spravochno-pravovaya sistema «Garant». [in Russian]

Programma razvitiya SYuT, 2020 - Programma razvitiya munitsipal'nogo byudzhetnogo uchrezhdeniya dopolnitel'nogo obrazovaniya stantsiya yunykh tekhnikov g. Sochi. Sochi: MBUDO SYuT v g. Sochi, 2020. [in Russian]

Programma tekhnoparka SYuT, 2020 - Programma FIP «Tekhnopark g. Sochi». Sochi: MBUDO SYuT v g. Sochi, 2020. [in Russian]

Razvitie obrazovaniya KK, 2015 - Gosudarstvennaya programma Krasnodarskogo kraya «Razvitie obrazovaniya» na 2016-2021gg. (utv. Postanovleniem ot o5 oktyabrya 2015 goda № 939 gubernatora Krasnodarskogo kraya V.I. Kondrat'eva). Spravochno-pravovaya sistema «Garant». [in Russian]

Razvitie obrazovaniya, 2014 - Gosudarstvennaya programma Rossiiskoi Federatsii «Razvitie obrazovaniya» na 2013 - 2020 gody» (utv. Postanovleniem Pravitel'stva RF ot 15 aprelya 2014 g. № 295). Spravochno-pravovaya sistema «Garant». [in Russian]

Rezapkina, 2000 - Rezapkina G.V. (2000). Ya i moya professiya. Programma professional'nogo samoopredeleniya dlya podrostkov [Me and my profession. Professional selfdetermination program for adolescents]. M. [in Russian]

Rezapkina, 2004 - Rezapkina G.V. (2004). Skoraya pomoshch' v vybore professii [Ambulance in choosing a profession]. M. [in Russian]

Rezapkina, 2005a - Rezapkina G.V. (2005). Otbor v profil'nye klassy [Selection in profile classes]. M. [in Russian] 
Rezapkina, 2005b - Rezapkina G.V. (2005). Programma predprofil'noi podgotovki dlya 9-kh klassov "Psikhologiya i vybor professii" [Pre-profile training program for 9th grade "Psychology and career choice"]. M. [in Russian]

Rezapkina, 2006 - Rezapkina G.V. (2006). Psikhologiya i vybor professii [Psychology and career choice]. M. [in Russian]

Rogov, 2003 - Rogov E.I. (2003). Vybor professii: Stanovlenie professional [Career choice: Becoming a professional]. M.: VLADOS-PRESS. [in Russian]

Savina i dr., 2001 - Savina M.S., Solntseva V.A., Savin A.A. (2001). Proforientatsionnoe soprovozhdenie professional'noi kar'ery [Career guidance professional career]. Metodicheskaya razrabotka. M. [in Russian]

Savina, 2004 - Savina M.S. (2004). Obuchenie tekhnologii poiska raboty [Training in job search technology]. Metodicheskie rekomendatsii. M. [in Russian]

Strategiya IR, 2011 - Strategiya innovatsionnogo razvitiya Rossiiskoi Federatsii na period do 2020 goda [Strategy for the innovative development of the Russian Federation for the period until 2020]. Spravochno-pravovaya sistema «Garant». [in Russian]

Strategiya RV, 2015 - Strategiya razvitiya vospitaniya v Rossiiskoi Federatsii na period do 2025 goda [The education development strategy in the Russian Federation for the period until 2025]. Spravochno-pravovaya sistema «Garant». [in Russian]

Tsifrovaya ekonomika, 2017 - Programma «Tsifrovaya ekonomika Rossiiskoi Federatsii» utverzhdena rasporyazheniem Pravitel'stva RF ot 28.06.2017 № 1632-r. Spravochno-pravovaya sistema «Garant». [in Russian]

Ukaz Prezidenta № 599, 2012 - Ukaz Prezidenta RF ot 7 maya 2012 № 599 «O merakh po realizatsii gosudarstvennoi politiki v oblasti obrazovaniya i nauki». Spravochno-pravovaya sistema «Garant». [in Russian]

Ukaz Prezidenta RF № 204, 2018 - Ukaz Prezidenta RF ot 7 maya 2018 g. № 204 «O natsional'nykh tselyakh i strategicheskikh zadachakh razvitiya Rossiiskoi Federatsii na period do 2024 goda». Spravochno-pravovaya sistema «Garant». [in Russian]

Vershinin, Surudina, 2001 - Vershinin S.I., Surudina E.A. (2001). Kak osushchestvit' professional'nyi vybor. Metodicheskie rekomendatsii [How to make a professional choice. Guidelines]. M. [in Russian]

Zakon ob obrazovanii, 2012 - Federal'nyi zakon Rossiiskoi Federatsii ot 29.12.2012g. №273FZ «Ob obrazovanii v Rossiiskoi Federatsii». M., 2020. [in Russian]

\section{Создание системы предпрофессиональной подготовки «юниор-профи» силами учреждения дополнительного образования}

Наталья Александровна Ковенко а, Ирина Алексеевна Лелюх ${ }^{\text {, }}$

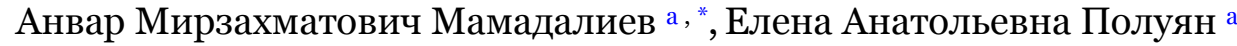

a Станция юных техников в г. Сочи, Российская Федерация

Аннотация. Статья посвящена анализу перспектив, условий, возможностей, проблем и рисков создания на базе учреждения дополнительного образования технической направленности, в частности, Муниципального бюджетного учреждения дополнительного образования Станция юных техников в г. Сочи, системы предпрофессиональной подготовки «Юниор-Профи» (JuniorSkills). В работе освещаются актуальность, цели и задачи проекта по подготовке «Юниор-Профи» в условиях города Сочи, а также его концептуальные основы; делается анализ уже проделанной работы в данном направлении в Российской Федерации и возможности создания соответствующей инфраструктуры для г. Сочи.

Ключевые слова: «Юниор-Профи», Технопарк, Сочи, город-курорт, МБУ ДО СЮТ г. Сочи, педагогическое моделирование.

\footnotetext{
* Корреспондирующий автор

Адреса электронной почты: anvarm@mail.ru (А.М. Мамадалиев)
} 